\title{
Review
}

\section{The Force of Nonviolence: An Ethico-Political Bind}

\author{
Judith Butler \\ Verso, London-New York, 2020, 224 pp. \\ ISBN 9781788732765
}

Judith Butler's latest release, The Force of Nonviolence: An Ethico-Political Bind, is a slender yet dense collection of essays animated by Butler's distinctive intellectual intensity and political engagement. It is a creative inquiry into non-violence as an ethical and political exigency, inextricably linked to the pursuit of social equality. Many issues raised in this book find echo in Butler's previous works whilst others appear as more novel, warranting meditation. Additionally, the book's saliency rests on its ambition to contribute to the ever-so-contemporary struggles for social (including gender and racial) equality.

In the introduction Butler's wager is clearly spelled out: understanding non-violence depends on understanding violence and this is not an innocent epistemic operation but always an ethical and political gesture. This is because 'violence' is a contested concept, neither empirically nor normatively settled, but always at stake, a crucial stake, in political struggles: naming violence is an instrumentum regnii which can enhance the power of whom has control over this practice by disqualifying, ethically, its opponents whilst justifying their oppression/elimination (p. 5).

Hence, a value-free definition of violence/non-violence is untenable or rather, always already a political decision. Coherently with this epistemic-ethico-political perspective, Butler proposes to chart those 'political frameworks' (p. 15) within which violence is elaborated and justified, to deconstruct their functioning diagrams and reality effects. This critical endeavour is then complemented by a praxeological effort: to oppose to those schemata an ethico-political framework, predicated on interdependency, which legitimises nonviolence as a never-exhausting tension toward equality (and which equality circularly fuels).

The first target of Butler's critique is the Hobbesian social contract, assumed as the foundational source of a whole political imaginary which hinges on violence as a pervasive pharmakon - both problem (the bellum omnium contra omnes) and solution (the Leviathan's sword and pastoral). Butler conceptualises this framework, drawing upon Melanie Klein, as a 'phantasy' (p. 35) - a partly unconscious and socially shared fantasy that structures our modes of perceiving. Namely, Butler takes issues with the Hobbesian phantasy's individualistic and non-egalitarian nature.

Hobbes, in fact, presupposes self-sufficient, always-adult and gendered individuals constituting the polity, endowing the Leviathan with their right to violence to prevent 
the pervasive yet potential violence of the state of nature. Against this backdrop, Butler argues that 'No one is born an individual; if someone becomes an individual overtime, he or she does not escape the fundamental conditions of dependency in the course of that process' (p. 41). Interdependency from others but also from structures, institutions, practices, objects, is what makes life possible (and as such prior logically and historically to individuation). It follows that, destroying 'the other' means, at a level of phantasy, to 'imperil one's own life' ( $p .95)$.

Yet, this originary social bond, modelled around the parent-child love/hate relationship, is not immune from violence: 'violent potential emerges as a feature of all relations of interdependency' ( $p$. 105), thus the issue becomes to reckon with such an ambivalence, without disavowing it (as Hobbes instead does), creating social obligations to check that potential whilst educating critically its 'bonding' power.

From this angle, Butler deconstructs the most elementary justification of violence self-defence. Deconstructing, here, entails something less (normatively) than invalidating. In fact, Butler circumvents, pragmatically, the general un/justifiability of self-defence, stating that 'nonviolence is not an absolute principle, but an open-ended struggle with violence' (p. 56), opening to some unspecified conditions under which self-defence would be justified. Instead, her focus is on unpacking self-defence by asking what is a 'self' and which are its boundaries. The 'self' of self-defence is an individualistic entity, a category predicated on the Hobbesian disavowal of interdependence and defined on 'demographic basis' (p. 55). This means that the identity of those I'm allowed to defend by recourse to violence are those lives written as grievable: registered as lives whose loss would matter and therefore ought to be safeguarded. The point, at once ethical and political, is to figure out the roots of the unequal distribution of grievability as a precondition of apprehending (and appropriating) violence, a Butler's well known theme at least since Frames of War (2009).

Mobilising Michel Foucault and Franz Fanon, Butler sees this discrimination between grievable and ungrievable lives as an expression of the 'make live and let die' biopolitical dynamic driven by historical racial parameters. Accordingly, it becomes possible to interpret the state-led disavowal of responsibility for the populations who are literally let die (p. 121) (e.g. immigrants drowning weekly in the Mediterranean Sea or minorities suffocated by police chokeholds), as a racialised biopolitical decision, enacted as 'necessary' violence and often justified in terms of preventive self-defence.

Is a 'more just' law the way to redress those inversions and safeguarding the ungrievable lives? Certainly not, Butler contends. Here, in a compelling dialogue with Walter Benjamin (p. 122), Butler engages with a critique of the legal-instrumentalist justification of violence. Law is a product of violence and to use it as the regulative framework of violence - as if violence which becomes law would magically purify itself - is an irrational double bind. Instead, we should look at what Benjamin calls, in his Critique of Violence, 'technique of civil conflict resolution'. This 'technique' is not 
designed to achieve an end; instead, it is an end in itself that 'exceeds both an instrumental logic and any teleological scheme of development - it is an ungoverned technique, arguably ungovernable' (p. 125). Such a 'pure means' would elude violence by rejecting both the superimposition of an external end and any form of 'legalisation', that is, of insertion in the order of the state. When and where is this technique in action? Or how to implement it? 'Language', Benjamin states, is the only place inaccessible to violence (p. 126). Butler interprets this cryptic statement in light of Benjamin's work on translation: the task of translation is 'furthering understanding where there was one impasse or even conflict', and its logic is the law of translation, 'a pre- or extracontractual technique of conflict resolution' ( $p$. 127). Translation intensifies communicability creating space for agreement, a space emptied by any justification of violence.

Nonviolence is this ethico-political operation of exposing which and how epistemic frameworks 'legalise' violence-as-a-means, whilst generating competing frameworks to intensify communicability by situating and naming practices of resistance (p. 147) which recognise/cultivate interdependency, without 'decaying' into law.

But advocating nonviolence without supporting equality is a dangerous exercise, Butler claims. Equality, here, is lives' equal grievability: every single life matters exactly the same, and this is the 'demographic precondition for an ethics of nonviolence' ( $p$. 56). This means that the 'interdiction to kill' entails addressing preliminarily the (biopolitical and racial) discriminations between those who are considered living and those who are not, the constitutive ambivalence of the violent potential of interdependency, as well as the unit of analysis of such operations.

Butler argues that overall this understanding should lead us to counter the biopolitical (preventive) self-defence which authorises the state-led killing/let-die of entire populations deemed ungrievable.

The book concludes with a praxeological proposal (p. 167), inspired by Sigmund Freud's notion of mania. Mania is a revolt against the superego's unrestrained power (which manifests itself by introjecting violence to counter violence) aiming to interrupt the 'vicious circle in which destructiveness is countered by self-destructiveness' ( $p$. 167). Butler here uses mania as an epistemic-political category: mania helps understanding 'forms of insurrectionary solidarity that turn against authoritarian and tyrannical rule' (p. 168). Although mania is not a political instrument, it does 'introduce[s] a vigorous form of "unrealism" into modes of solidarity' (p. 171) against tyranny. This perspective is well illustrated in the postscript to the book, dedicated to the 'Ni Una Menos' movement against 'feminicidio', that is, to the Latin American (now global) movement against the systemic-heteronormative violence predicated on the ungrievability of women's lives. 
'Ni una meno' politicises mania by the deliberate exposing of bodies to power, endangering (further) protesters' lives. The exposure of dependency here is not an impasse but a condition of productive, non-individualistic, social bonds. This tactic does not intend to create fix 'vulnerable identities' (as state agencies sometimes do in paternalistic way) but to express a type of (nonviolent) strength against (violent) individualistic power (p. 202), in a context where equality is demanded and the ambivalence of social bond acknowledged.

The Force of Nonviolence is an 'untimely' book, an intervention against our time, marked by non-violence's minimal popularity and even less political currency. Butler tries to enfranchise non-violence from its popular representations as 'stoic' practice, highlighting its organic ambivalence, as always already enmeshed with aggressivity, and its intellectual ambiguity, as at once a socio-political and psychic entity.

A critical book, aiming to uncover the condition of our present way of reasoning about violence and non-violence, deconstructing both instrumental definitions of preventive self-defence and left libertarian approaches to non-violence as an unrealistic divertissement. The book does not provide a rational justification for nonviolence. Instead, it reformulates, with respect to nonviolence, Butler's key themes around the structure of social bonds, their psychic lives and ethico-political potential.

A number of conceptual and meta-theoretical dissonances make the book even more generative. The idea of nonviolence as something less than an absolute principle renders the book's proposal pragmatic but also slightly ambiguous and normatively impoverished. The dialogue with Benjamin is fascinating but, following Hannah Arendt and Jacques Derrida, Butler over-cautiously disavows a confrontation with the messianic/an-archist import of Benjamin's 'divine violence'. The aggressivity implicit in any social bond is a key contribution, but there is little on how to check socially its destructive potential, apart from a line on 'global obligations'. Overall, the book hinges on Butler's well known endeavour to cast epistemic, ethical and political spheres against a psycho-social backdrop. The result is the blurring of any threshold between the normative, the psychic and the organic, between nature and logos, with continuous (at times disorientating) shifts from explaining to justifying non-violence. Provocation here lies in the (deliberate?) chaos produced by these naturalistic fallacies whilst gathering Foucault and Fanon, Freud, Klein and Benjamin, thoroughly 'bricolaging' their thoughts beyond any philological and historical consideration.

Butler's voice is and has always been an exception to Roland Barthes' idea that the death of the author is (and ought to be) the birth of the reader. This is because Butler's lively ecriture feminine does not conclude, cannot be enclosed, her generative (and sometimes dissonant) interpretations shake and provoke, galvanising the reader more than soliciting acquiescent analysis. This is also the force of this book: an unsettling, inventive and provocative ride against the stream of our time. 


\section{References}

Butler, J. (2009) Frames of War: When is Life Grievable? London-New York: Verso.

\section{Giuseppe Maglione}

Edinburgh Napier University 